\title{
SNS in India: Gossip as a Vehicle of Activism
}

\author{
PAULA RAY, University of Auckland
}

\begin{abstract}
Statistics indicate that Facebook has more women users than men. A Mashable report released in 2010 claims that women in the age-group of 18-34 check their Facebook first thing in the morning, even before going to the bathroom. This can be linked to the chatty nature of interaction within social networking sites (SNS). Gossip need not be flippant, but can gratify the actor, as evident from the women's communities actively promoting causes online and garnering public support for social, economic and political issues. SNS is quickly becoming a means of facilitating gender-based activism. What makes it more interesting, these women do not have to shun their domestic duties to become an actor in these global networks; they can very well partake in it from the confines of their kitchen. It can be argued that SNS has overcome the limitation of the 'gendered media' and has provided activists with the vehicle to organize their cause and promote participation for cross-border movements traditional means of activism were perhaps never as swift. But how do they draw on SNS, particularly Facebook, to further their causes and what is the nature of the issues they engage in? To explore these questions, I take up India as a case study. Initial research indicates that digital activists are raising concerns about the way this communication tool is being used and the kind of the issues being raised.
\end{abstract}

\section{KEYWORDS}

social networking, women, India, activism, gossip, Women2Drive, Pink Chaddi campaign, Motrin Moms

\section{Introduction}

In recent years, women have become highly active in building up political communities on the Internet, particularly in the interactive version of information exchange (Knights 2007) known as Web 2.0. These communities, formed through the social networking sites (henceforth referred to as SNS) that are considered to be the most definitive feature of Web 2.0 (Gauntlett and Horsley 2000), use digital forums to facilitate social activism in cyberspace. According to statistics, Facebook, which is the most popular SNS (Pempek et al 2009) with a billion active users (Facebook 2013, n.p.), has had a phenomenal rise in women users. A survey conducted by the website InsideFacebook.com concluded, 'the number of US women over age 55 using Facebook grew by $175.3 \%$ between September 2008 and February 2009' (Smith 2009, n.p.), while Rapleaf (2008), a Web 2.0 consumer research organization, claims that women in the 30 to 50 age-group are the fastest-growing segment of SNS users. What makes it more interesting is the fact that 'women [56.2\%] on Facebook in the US outnumber men in every age group' (ibid., n.p.). A report released by technology and social media news site Mashable also highlights women's increasing association with Facebook: '[A]s many as one-third of women aged 18-34 check Facebook when they first wake up, even before they get to the bathroom' (Parr 2010, n.p.). At a Blogher Conference in 2010, the 
digital business analytics company comScore (2010) released a report stating that not only is the number of women on cyberspace higher than that of men, but they also engage in social networking as their primary online activity. Women spend an average of 5.5 hours per month on SNS, according to the comScore report, compared to 3.9 hours spent by men. But given their high usage, are women SNS users expanding this capacity to digital activism?

This article focuses on how urban Indian women Facebook users draw on SNS to further their activist causes, along with the nature of the activities they engage in. I argue that it is the gossip-based communication model of Facebook, described as 'idle talk' (Rysman 1977, 176), that acts as 'a catalyst of social process[es]' (Paine 1967, 283) and spurs higher involvement amongst women users. The bonding quality of such an interaction has the potential to unite a range of feminist voices by overcoming their geographical and cultural differences via Facebook interaction. To ascertain the nature of Facebook usage and the rationale behind such practices, I conducted open-ended interviews with five experts in digital activism in India. They are experts in the sense that either they have engaged with digital tools of communication to launch or promote their activist campaigns, or they are analysts who circulate their observations on digital activism via blogs. Each of them was asked how they use SNS to voice their concerns and causes, and if, in the process, they have shunned traditional tools of activism. The article begins with three case studies of SNS activism, not only from India but from across the world. This is followed by an analysis of the relationship women have had with communication tools over the years, and how SNS is changing this gender equation. I situate gossip as the binding force that has pushed SNS usage in favour of women and I take up India as a unique case study for this purpose, substantiated by expert opinion.

A number of international cases have made this gendered shift in digital activism visible. On June 17 2011, the Women2Drive campaign was launched in Saudi Arabia to protest the religious ban imposed on women drivers (Al-Shihri 2011). Dozens of videos surfaced on social networking sites showing local women taking to the wheels of their cars rather than depending on hired drivers or male members of the family to drive them to their destinations. Following this, several women drivers were physically abused for going against Arabic tradition. The campaign had been spearheaded by Manal al-Sharif in May 2011, who put up a YouTube video of herself taking a test drive, urging women to follow suit. In the video, she says, 'This is a volunteer campaign to help the girls of this country [learn to drive ...]. At least for times of emergency, God forbid. What if whoever is driving them gets a heart attack?' She started a Facebook page called 'Teach me how to drive so I can protect myself', requesting the authorities to lift the ban. Instead, she was detained by the police and forced to sign an agreement saying she would not drive again. In protest, the Women2Drive campaign took off by forming a Facebook group with the same name, which is now actively gathering comments that pour in continuously from Facebook users across the globe, with the 'likes' accumulating daily.

On September 30 2008, in a breakthrough case of digital activism in the US, mothers responded to an online and print advertisement launched by Johnson \& Johnson so strongly that the company was forced to withdraw its advertisement before the end of the week, with the marketing vice president issuing a public apology over the weekend for hurting the sentiments of young mothers. The protest was against an advertisement for a pain-killer 
called Motrin aimed at mothers who carry their babies in slings. The advertisers referred to the practice as a fashion statement made at the cost of suffering from back pain. This offended the mothers and they started a campaign on Twitter with the hashtag \#MotrinMoms (Petrecca 2008). The campaign gathered momentum so fast that the product company did not even have time to react before it spiralled out of control.

On February 5 2009, the Pink Chaddi campaign launched in India found an expression for the nationwide outrage against Shri Ram Sene, an extremely conservative Hindu political group, when their activists beat up a group of young women at a Mangalorean pub. The Hindu group claimed that women who wear western clothes and drink alcohol at pubs violate Indian tradition. By coincidence, a local journalist, Nisha Susan, was also present at the incident. She decided to set up a Facebook group called 'The Consortium of Pubgoing, Loose, and Forward Women', and urged women to gift pink chaddis (panties) to Pramod Mutalik, who heads the political outfit, to stop him from disrupting forthcoming Valentine's Day celebrations (Mishra 2009). It became so successful that today it is considered one of the best examples of digital activism in India. It brought together Indian women from across the world to take collective action (Banerji 2010; Hariche, Loiseau and MacErlaine 2011), using social media tools.

Perhaps for the first time in the history of communication technology women are using a communication tool more frequently than men (Wajcman 2004). In spite of the potentially overwhelming commercialisation of the market research outcomes mentioned above, they evidently reinforce the fact that women 'like communication and community building on the net' (van Zoonen 2001, 70). A technology like SNS simply 'enhance[s] the possibilities' (ibid., 69) for such practices and hence offers opportunities for increased participation. Social media increases women's scope of action and provides new opportunities for sharing their concerns, from traditional women's issues to real-time chat options on topics that have traditionally been considered socially unacceptable. This, in turn, not only boosts the political potential of SNS, but also reconstructs the commonly 'gendered distinction between consumption and production, between entertainment and information' (ibid., 68) across media forms. Engaging in feminist reflection on the function of the web in the 1990s, Dale Spender (1995) referred to the Internet as a medium for collective networking for women, while Sherry Turkle laid emphasis on the 'construction of identities' (cited in van Zoonen 2001, 68) that it made possible. Sadie Plant took this further by highlighting the 'affection, intimacy and informality' $(1998,144)$ that this technology facilitates across its networks. Extrapolating these insights to the greater interactivity found in Web 2.0, it can be said that Web 2.0 has made advances in overcoming the gender stereotyping of media (Wood 2008), whereby mass media not only tends to portray women in a negative light, but also represents technologies as predominantly male-centric. Although normative gender stereotypes still tend to be defined largely by what we see on-screen or read about in various mass media channels, Facebook usage statistics show that women too can be technologically savvy, which they can perhaps utilise to further their cause.

\section{Women and SNS}

Web 2.0 has achieved something that none of the previous communication technologies could (Wacjman 2004). The technologies of telephone and radio arrived with a similar promise of radical emancipation from hierarchical structures of power, but they ended up 
creating a set of elites who controlled the flow of information. The Internet came with the same promise of connecting people, but this time it was said to be a true leveller (Spender 1995). Women's reticence to use technology can historically be attributed to the social exclusion of women from science and technology, according to Spender. The arrival of the Internet has gradually changed these dynamics between women and technology. This can be partially attributed to the fact that, unlike traditional forms of knowledge that were acquired by observing and reflecting in isolation (Code 1991), in the digital information age knowledge is gained through interacting with others, which by definition connects it to the community-building exercise at which women are normatively considered adept (Reinharz 1983). The democratic potential of the Internet, especially Web 2.0, is to be found not only with regard to equal rights between the sexes, but also with regard to social background and economic independence of women (CBFW 2010). SNS in particular can be accessed by women at their workplace, in a public Internet cafe or from their home. Ever since Internet services have gone wireless, access nodes have been multiplying and users can link in from virtually anywhere within the web of connectivity (Lehr and McKnight 2003). The vast amount of information made available across this web of connectivity (Shapiro and Varian 1999 ) is now expected to gradually wipe out our dependence on manuscripts (Naughton 2006) and goes well beyond what a single person can read through in his or her entire life. With so much information available literally at one's finger-tips, Web 2.0 has been framed as a potentially democratic tool (Dutton 1999), as this access to information is making citizens aware of their rights while virtual tools are making it easier to fight for them. It is this access to SNS connectivity and the swiftness of SNS communication that perhaps aided Manal alSharif in spreading her YouTube footage among fellow Arabic women, and the world, to protest the discriminatory driving laws.

Turkle (1984) and Donna Haraway (1991) have argued that women's traditional fear of the machine - and specifically, in terms of my concerns here, the computer - has gradually been replaced by curiosity. Now the moment seems to have finally arrived when

[the] Internet has emerged as a powerful medium for non-elites to communicate, support each other's struggles and create the equivalent of insider groups at scales going from the local to the global. The possibility of doing so transnationally at a time when a growing set of issues are seen as escaping the bounds of nation-states, makes this even more significant. (Sassen 2002, 117)

Issues of 'struggle' for women in the digitised world could range from human rights and work rights to more localised concerns. Importantly, the Internet is not only providing women with a forum to discuss their concerns but also to join forces in voicing their grievance beyond their immediate community. The Internet, or rather SNS, has provided them with the vehicle to expand from their niche location and reach the world, so that local struggles ultimately become recognised and embraced trans-locally, thus facilitating crossborder activism. The activists are constantly connected with each other through digital means facilitated by SNS. In fact, digital connectivity makes it easier for these women located far and wide to be in constant touch and be quick in organising movements; traditional means of political participation and organisation were perhaps never as swift (van Dijk 2000). What is more interesting is that these women do not have to shun their domestic duties to become an actor in these global digital networks; they can very well join in from the confines of their kitchen and navigate the political implications of their personal concerns, much like the slogan of second wave feminism, where 'political' referred to power relationships rather than 
electoral politics (Hanisch 2006, n.p.). This is precisely how it was possible for a group of young mothers with babies in arms to force a multinational corporation, Johnson \& Johnson, to withdraw its publicity campaign aimed negatively at women, and also to extract a public apology.

Communicative gestures on Facebook, like 'commenting' on a status message or 'posting' your own status update, are used mainly to connect with one's network. This kind of relationship inclines towards what Anthony Giddens calls 'constant communication and reflexive practice' (cited in Miller 2008, 389) built on mutual trust. It is enacted in the way we frequently renew and refresh our contacts list on Facebook, and almost instinctively respond to the posts and updates of our 'friends'. It is not what you write to friends through narrative communication, which 'raises unanswered questions or unresolved conflict; and provides resolution' (Hinyard and Kreuter 2006, 778), but how you keep in touch - through comments, tags, status updates and messages - that has given rise to the 'database culture' in the digital age, helping users to reach out to an increasingly wider social base. This form of networking, in turn, blurs the notions of 'presence' and 'absence' (Licoppe and Smoreda 2005,318 ), thereby imparting a feeling of being in constant touch with family and friends. In other words, it radically undermines the issues of distance and time associated with traditional means of communication. A user is likely to communicate with his or her active Facebook contacts at least once every 24 hours, if not more frequently, irrespective of physical distance and different time zones (Ledbetter et al. 2011). It creates a 'connected presence' (Miller 2008, 387) which is increasingly dominating media culture.

Despite the virtual nature of these often distanced connections, SNS is based on the concept of face-to-face communication, referred to as phatic communication in the area of linguistic studies. Phatic communicative acts are conventionally understood to take place at the bodily level and be expressed through movements such as eye contact, posture and facial expressions. These acts are woven together with verbal conversation, and go beyond establishing a social union (Laver 1975); phatic communication establishes a deeper understanding based on the interaction between the actors that is not strictly expressed in words. The additional gestures help in the transition through various phases of conversation starting a conversation, carrying it forward and also ending it on a note open to future encounters. SNS chats are based on similar principles, with emoticons and multimedia expressions making up for the now-absent body.

To keep in touch with an ever-expanding network of contacts, Facebook users often end up chatting or sending offline messages almost on a continuous basis (Ledbetter et al. 2011). The multi-tasking thus involved has become a primary characteristic of our lives in the digital age, and in order to continue building social bonds within this environment our communication has evolved to become 'non-linear, open-ended, and highly ambivalent' (Beck and BeckGernsheim, cited in Miller 2008, 388). At no point does a Facebook user pay complete attention to one particular interaction; she is either reading her friend's updates, commenting on them, posting updates, chatting with another friend or sending a message to yet another friend. Her attention is fragmented by all these tasks (Backstrom et al. 2011). However, as in any relationship, the bond between the actors strengthens with the growth of mutual trust (Ledbetter et al. 2011). The inconsistencies sown by the distracted communication of Facebook are countered by its model of constant access which breeds familiarity and builds 
up trust, even if it is practiced within the structure of a virtual community. The interactive nature of SNS which breeds familiarity has helped this medium of communication gain the faith of its users. The more contacts they add to their Facebook list, the more secure they feel in the thought that they can connect with their 'friends' at the press of a button. This can be compared to Robert Putnam's concept of 'social capital' (2000) that result from collective social interactions with the strong and the weak ties (Granovetter 1973) within the social network. Thus, there is a non-face-to-face phatic (Kendon, Harris and Key 1976) culture associated with SNS that is aimed at maintaining social connections rather than necessarily carrying information to the receiver of the message. By virtue of its non-intrusive nature, as compared to a dialogic communication, a Facebook message manages to deliver expressive information to the receiver's inbox without necessarily making it obvious. The chatty nature of the message it carries is easier on the recipient, as opposed to an information-heavy message that would demand more time and attention to acknowledge or even to reply to. For example, expressing solidarity with Anna Hazare's India Against Corruption movement, on a Facebook group ${ }^{1}$ based on that movement, a member writes: 'Go on...Untl v achv d fnl gl', while another member rationalises: 'seacond $[\mathrm{sic}]$ hero after bapu [referring to Mahatma Gandhi] i support $u$ in all way and all d corrupted neta [leader] hang on.' A third member posts: 'Am with yu sir...'. These are some examples of what I term gossip-based communication that the users engage with within Facebook.

All forms of communication technologies are gradually combining and mediating through the SNS platform (Ross et al. 2009); emails are likely to be replaced by what we know as Facebook messages and cellular phone texting will perhaps mutate into micro-blogging or even status updates on SNS. This is expected to become more convenient with the increase in the usage of mobile Internet. Cellular phone users have already reached a phase where they send a text message asking if it is convenient for the receiver to receive their call, before they actually call up their contact's cellular number. Turkle (2011) narrates the incident of a mother who decides to pay her prospective nanny a surprise visit to interview her for the job, only to find that the nanny's housemate offers to send a text message to inform the interviewee about her guest. Thus, Turkle argues that 'texting puts people not too close, not too far, but at the right distance' (ibid., 15). This has made text messaging the most appropriate communication etiquette in the postmodern digital society. In the near future, presumably, SNS-users will tweet or send a chat message instead of a text message. But since a tweet or a Facebook 'comment' can reach more than one person simultaneously, this kind of communication also has the potential to break down the one-to-one nature of phatic contact in order to spread a message and promote a cause.

\section{Gossip and SNS activism}

As I have shown, statistics hint at a shift in the gender usage of this communication technology, a core cause of which can be attributed to the expressive, proximate nature of interaction within SNS. Such a form of interaction, verging on gossip, can bring people together into cause-related configurations even across gulfs of time and space. In this sense, 'gossip is a catalyst of social process' (Paine 1967, 283) that gratifies the actor and serves her self-interest. This is very similar to her experience when she engages in a quick chat on

\footnotetext{
${ }^{1}$ To maintain confidentiality, names of specific Facebook groups and users whose comments have been cited, have been kept anonymous.
} 
Facebook (Ellison et al. 2007), irrespective of where she or her friend is located. As Robin Dunbar argues:

gossip has taken over the social function of grooming. Instead of removing lice from each other's hair, people check in with friends and colleagues, ask how they are doing, and exchange a few words about common acquaintances, the news, or the local sports team. (cited in Donath 2007, 231)

The bonding that such acts foster ensures trust among the participants in times of crises. Similarly, the fundamental structure of SNS is designed to develop trust and reliability among online users, often through communicative activities that are apparently trivial. However, an individual aware of the implications of trust-based communication (Ledbetter et al. 2011) can use the act of gossip to convey the information she wishes to spread within a specified group. When Nisha Susan urged her Facebook contacts, over chats and status updates, to gift pink panties to the reactionary political party workers on Valentine's Day, it was initially brushed off as a humorous, and hence trivial, attempt at protest. What began as another topic of gripe and gossip among friends started making national headlines when the 'likes' for the post began accumulating into thousands, with women commenting on it from across the world. But the extent to which this campaign had connected women across geographical and cultural boundaries became evident only when the responses started physically reaching the party office in the form of gifts. This impact of digital activism is comparable to the 'likes' Manal al-Sharif's Women2Drive Facebook page is receiving even today.

The term 'gossip' 'assumes gender - not only because women gossip, but, more importantly, because gossip is the sort of thing women do' (Spacks 1982, 22). Gossip is actually 'idle talk' (Rysman 1977, 176) that gradually melts the inhibitions between or among the actors involved in it, to a point where they start sharing personal experiences. This shared revelation of private matters has healing powers (Spacks 1982). In this way, gossip can transmit useful information as well as promote social solidarity. Laurie Colwin compares gossip with 'emotional speculation' (cited in Spacks 1982, 19), because by talking about others, people also find out about their own selves; it is interpretative in its essence. Such conversations help the actors measure their own experiences against that of others and also assess their own judgement in similar situations. Although hardly a theorist of gossip, Jürgen Habermas too has referred to the 'conversation of intimate equals in the lifeworld' (Peters 1993, 564) within the public sphere as the perfect communication model. Thus, gossip can be considered an affirmation of alliance.

SNS is providing women in particular with a vehicle to carry over their gossip into the virtual world. Gossip is not necessarily flippant or spiteful; rather, Ralph L. Rosnow and Gary Alan Fine refer to gossip as 'talk with a social purpose' (cited in Holland 1996, 200). A Facebook group campaigning against sexual harassment in India posted the video of an advertisement of a cellular phone on its wall and attracted several critical comments from the group members. In the commercial, a leading national level cricket player from India, Virat Kohli, endorses a cellular phone by showcasing to his group of young friends how the unique features of the device makes it easier to speak to random girls and even impress them. The derogatory overtone of the narrative infuriated the group members and one of the members explains it thus: 
It's funny ...in the first instance I couldn't decide if this is harassment....i guess over the years 'normalization' of certain kinds of behavior happens. Also because the guy is 'Virat Kohli' the hero image overpowers the harasser image .......BUT we need to wake up ...yes this is harassment of a sneaky kind ....can $u$ imagine 1000 s of boys trying this and thinking nothing is wrong with it cause Virat did it ......and we are 'normalizing' this through ads .why don't they turn the ad around with a group of girls harassing the boy instead .....

In this way, the digital platform facilitates a much smoother and non-violent protest, even if the comments are reactive and reflective of women's angst.

Thus, unlike merely chatting about vacation plans or the weather, gossip as a form of evaluative and comparative talk involves discussions about others' lives. The gossip in which the consciousness-raising groups of Second Wave feminism engaged had a political intent that is still relevant to SNS today, as it aimed at sharing experiences and distributing information. This kind of communication, when mediated through SNS, helps unite women who have like-minded concerns or issues. By showing empathy towards a person suffering from some kind of grief, for instance, the actors involved in a gossip solve their own issues that may be similar to the ones they are talking about. During the course of this exercise of discussing other people's lives, the actors reach a comfort zone and begin confiding in each other about their own personal experiences (Tachhi 2010, n.p.). When they talk about their own difficulty or trauma with a person they trust and are comfortable with, it helps them discharge their pent-up emotions and release tension. Talking about it might also create a different perspective on the incident that could open up new avenues for coming to terms with the experience. It could be a moment of meta-commentary (Huhtamo 1995) shared between the friends, where they go through the processes together while discussing the steps that led to the unfolding of the incident, the decisions they made and the intentions that prompted them. By the end of such an intense analysis, the friends would have walked a long road together and shared some very private moments. In this way, gossip can promote social solidarity, in the form of empathy between the actors, and also transmit useful information because the actor who listens to her friend's experiences ends up also comforting and advising, which often takes the form of advocacy. Gossip, thus, is not trivial in its effects; an activist can use it to spread the word, impact decision-making, influence legislative amendments and potentially bring about changes in society. This is how Facebook and other SNS usage is facilitating activism on cyberspace, as evident from the Pink Chaddi campaign. It started off as gossip among online friends and eventually took the form of a protest movement with direct results.

\section{Indian women and SNS activism}

But why do women draw on SNS as a digital communication tool over others, and more importantly, what is the nature of the activities in which they engage? To explore these questions, I take up India as a case study. India has the second largest number of mobile Internet users in the world (Eluvangal 2010) and the mobile phone has penetrated far into the rural landscape, which constitutes 70 percent of the population of the country (World Bank n.d.). The language barrier endemic to this multi-lingual nation has also been overcome by enabling both mobile technology and SNS usage in vernacular languages. Given the popularity of SNS, new-age mobile phone sets are already enabled with SNS-buttons that are easy to navigate. But, in spite of such high technological advances in the country, 
economically speaking India is considered a developing nation that houses a population of 410 million living below the poverty line (ibid.). The apparent economic development that the country has experienced is restricted to a certain section of the urban populace. The wealth earned through economic growth seldom percolates down to the masses, mainly because of lack of adequate infrastructure and deep-seated corruption within the system. This, in turn, has resulted in an ever-widening economic gap between the urban and the rural populations. As such, the Eleventh Five-Year Plan (2007-12) has been formulated to achieve 'inclusive growth' (Deloitte 2011,3) to overcome the wide disparities in the economic conditions of the people. In keeping with the plan, mobile telephony has been targeted as having the potential to ameliorate the socio-economic variability of the country's population by making SNS available to the masses, which in turn can connect millions of users instantly and efficiently. Such connectivity can have economic impact, but Indian SNS users are first expanding this capacity into sociality and by extension digital activism.

Based on her field survey in India, Jo Tacchi (2010) describes the mobile phone as a tool that appears 'prominently and emphatically in the data about the women's "communicative ecologies"' (n.p.). The mobile phone as a communication technology has opened up avenues for intimate conversations among women in India. Tacchi reports on rural Indian families where the mother feels comforted because she can interact with her married daughter every day about things that cannot be discussed over landlines located in the centre of family homes. The mobile handset can give her daughter freedom and privacy from her in-laws, with whom she resides in the same house; daughters and mothers can speak comfortably without being overheard by the husband or his family. Tacchi writes, 'This is a significant relationship for these women' (n.p.). If this is the impact the mobile phone has on its women users in rural parts of India, we can only imagine the potential of SNS access through the mobile Internet by these same women in the near future.

In my interviews with experts on digital activism in India, I found that they were all beginning to use SNS for political purposes, though not all of them were positive about the democratic power of SNS. Urvashi Butalia, the first feminist publisher in India (her publishing house is called Zubaan Books), uses Facebook to get in touch with readers of her publications. 'It enables a dialogue with the fan base, much faster than writing letters' (Butalia, interview, January 2011). Jasmeen Patheja, co-founder of Blanknoise, a campaign against sexual harassment, uses SNS as a public platform to launch events and also mobilise people on the streets: 'it is a back and forth process', she says (interview, January 2011). One of the most popular Blanknoise digital events, the 'I never ask for it' campaign, asked members to put up status messages on their Facebook page about sexual harassment without mentioning it directly. At the end of the message, they would add, 'I never ask for it'. The event went viral, with even men responding to it. Sonali Khan of Bell Bajao, a campaign against domestic violence that has a strong SNS presence, refers to a case in Abu Dhabi, UAE where a victim of domestic violence got in touch with them via Facebook, in response to which another member from Dubai volunteered to help her out through a comment on the Facebook post. Though the campaign is based in India, the Facebook group helps them reach out to activists beyond their own territorial limits.

Unlike technological optimists who highlight the far-reaching impact of Facebook usage, the most common level of engagement is to 'like' or 'share' an FB post, but these acts are also 
potentially powerful in promoting awareness in the digital world by spreading the word. For instance, during one of the busiest weeks (December 24 - December 31, 2012) for the Hazare Facebook group referred to earlier, there were 41 updates posted on their wall, receiving 196 comments, 2267 'likes' and 103 'shares'. The heightened traffic had resulted from the New Delhi gang rape incident on December 16 2012, as most of the posts and comments were about this occurrence. Digital outreach does not mean that activist organisers give up on traditional means of protests like street demonstrations and physical congregations at city centres. It does, however, mean that these protests can be organised with a speed, efficiency and ferocity that is unprecedented. Commenting on the usage of SNS in these uprisings, Peter Beaumont writes,

The medium that carries the message shapes and defines as well as the message itself. The instantaneous nature of how social media communicate [...] explains in part the speed at which these revolutions have unravelled, their almost viral spread across a region. (2011, n.p.)

In the most recent Indian event that gathered social momentum at viral speed, it took only two days to track down four of the six accused in the New Delhi gang rape case (IBNLive 2013, n.p.), while outrage spilled over from the online platform to the streets of the capital city. Protests from 'the youth across class and caste divides' forced the government to set up 'an independent commission led by former Chief Justice of the Supreme Court, J S Verma, to recommend changes to its rape laws' (Parashar 2013, n.p.). In this way, both online and offline, digital and traditional tools of protests combined to yield results.

SNS helps in spreading the word and organising a movement much more swiftly than traditional tools of communication, but this does raise the question of the consistency and effectivity of its real-world impact. SNS can be considered as simply one of the means, albeit a very crucial one, that leads to the final objective of an activist. Distinctions must be made, however, between types of campaigns, since SNS activism works best on the basis of friendto-friend chatty intimacy, believes Mumbai-based blogger Dina Mehta. She says, SNS can amplify the cry for help: 'It can make a lot of noise with regard to micro causes - idiomatic, one-off campaigns, like eve-teasing [a euphemistic expression commonly used in India to refer to random instances of sexual harassment that women are subjected to on the streets]. However, it does not work in the case of bigger causes like eradicating sexual harassment' (interview, January 2011). SNS managed to organise street demonstrations within the country and draw the attention of the world to the Delhi gang rape case, as evident from the regular updates reported on by leading media outlets, such as The Guardian, the $\mathrm{BBC}$ and The New York Times. But ongoing sexual harassment of women and young girls, at home and on the streets, is still a cause for concern in Indian cities. Mehta also points out that online access is limited to urban elites. What about the rural population with limited infrastructural support? So far they can be mobilised only in person. SNS activism is a distant dream for them, until vernacular access of SNS through mobile Internet reaches the interiors of these villages. In this sense, SNS activism is limited by the economic situation of the people, their literacy level and access to technology, resulting in the current digital divide (Singh 2010) between the urban and the rural population.

The greatest effect of digital media, albeit in urban and relatively economically affluent centres, lies in the 'often loose and non-hierarchical organisation of the protest movements 
[that are] unconsciously modelled on the networks of the web' (Beaumont 2011, n.p.). Beaumont also notes, however, that such loose movements cannot contain the political effects of digital activism. The success of the Pink Chaddi campaign prompted the Hindu political group to counter it by launching their own Pink Condom campaign (Dudeja 2013) and posting comments on Facebook, such as, 'Go and enjoy in pubs, but do not forget to use the pink condom sent to you guys'. In this case, SNS was used by both the activists for the cause as well as the counter-activists. Used equally to foment social change and to crack down on the fomenters, SNS is not tied to one political ideology or solely to the function of releasing the voices of the oppressed. Although it can be used to gather support across territorial boundaries or as a tool to facilitate activism through the sharing of experiences, real-world effects continue to require real-world engagement. Thus, SNS is a prime means of enabling activism, but it is not an end in itself.

\section{Conclusion}

While SNS is being used extensively by activists, many of whom point out its limitations, there remains a sense that there is a greater future for SNS activism, especially with regard to feminist movements. Swati Parashar cites the New Delhi gang rape case to call for a 'rethink of third wave feminism and its ethical and political commitments' (2013, n.p.). She says that violence against women has been 'documented as common to all societies' (ibid.), as it affects women in general and is not dependent on their cultural and ethnic background. It is the diversity of experiences that adds richness to feminist understanding, and SNS is particularly good as a platform for sharing multiple experiences. Selective channels of outrage show that feminism has so far not overcome cultural barriers when it comes to advocacy, but the increasing penetration of SNS into these economies may begin to change that. This is the bridge SNS-mediated activism can aim to construct by dissolving the physical location of the activist as a factor in the interaction, so that universal humanitarian laws and equality can be advocated for all.

The democratic reach of SNS, primarily in terms of access to information (Dutton 1999), can make possible transnational feminist dreams of a world united across many colours, ethnicities, nationalities and cultural backgrounds, as reflected in the response the Pink Chaddi campaign received. Since SNS is accessed through various channels by women across the world, it can assist in their vision of transformation by weaving a network of communication through forms of discussion weighted lightly as 'gossip'. SNS-mediated activism can then be said to have the potential to realise Chandra Talpade Mohanty's transnational vision of 'a world where women and men are free to live creative lives [...] in which democratic [...] institutions provide the conditions for public participation and decision-making for people regardless of economic and social location' $(2003,4)$. Ultimately, this gossip-based communication tool has the potential to bridge the conflicting visions of various feminist waves by facilitating discursive networking among activists across borders, and to unite them for a common cause. That could well constitute the most important realworld end of SNS-based activism for feminist causes. 


\section{REFERENCES}

Al-Shihri, A. (2011) 'Saudi Woman Held by Police - for Driving', Independent.co.uk, [online], 22 May. Accessible at http://www.independent.co.uk/news/world/middle-east/saudiwoman-held-by-police-ndash-for-driving-2287650.html. Accessed 26 September 2011

Backstrom, L., Eytan, B., Kleinberg, J., Lento, T. M. and Rosenn, I. (2011) Center of Attention: How Facebook Users Allocate Attention Across Friends, Proceedings of the Fifth International AAAI Conference on Weblogs and Social Media, Association for the Advancement of Artificial Intelligence, [online]. Accessible at http://misc.si.umich.edu/media/papers/attention.pdf. Accessed 12 November 2013

Banerji, R. (2010) 'The Pink Panties Campaign: The Indian Women's Sexual Revolution', Intersections: Gender and Sexuality in Asia and the Pacific, 23, January, (n.p.)

Beaumont, P. (2011) 'The Truth About Twitter, Facebook and the Uprisings in the Arab World', Guardian.co.uk. [online], 25 February. Accessible at:

http://www.guardian.co.uk/world/2011/feb/25/twitter-facebook-uprisings-arab-libya. Accessed 22 April 2013

CBFW (2010) 'Women \& Mobile: A Global Opportunity', [online]. Accessible at http://www.cherieblairfoundation.org/women-and-mobile-a-global-opportunity/. Accessed 19 October 2013

Code, L. (1991) What Can She Know? Feminist Theory and the Construction of Knowledge, Ithaca: Cornell University Press

comScore (2010) 'Social Networking Sites Reach a Higher Percentage of Women than Men Worldwide', [online], July 28. Available at http://www.comscore.com/Press_Events/Press_Releases/2010/7/Social_Networking_Sites_R each_a_Higher_Percentage_of_Women_than_Men_Worldwide. Accessed 26 September 2011

Deloitte (2011) Inclusive Growth: A Challenging Opportunity, [online]. Accesseible at http://www.deloitte.com/assets/dcom-india/local\%20assets/documents/inclusive_growth.pdf. Accessed 4 October 2013

Donath, J. (2007) 'Signals in Social Supernets', Journal of Computer-Mediated Communication, 13(1), 231-251 
Dudeja, S. (2013) 'Studying Alternate Protest in Cyber Space', Coldnoon: Travel Poetics, [online], 2(2), 87-96. Accessible at http://www.coldnoon.com/pdf/Coldnoon_TravelPoetics_Mar\%2713/SapnaDudeja.pdf.

Accessed 12 November 2013

Dutton, W. (1999) Society on the Line: Information Politics in the Digital Age, New York: Oxford University Press

Ellison, N. B., Steinfield, C. and Lampe, C. (2007) 'The Benefits of Facebook "Friends": Social Capital and College Students' Use of Online Social Network Sites'. Journal of Computer-Mediated Communication, 12(4), 1143-68

Eluvangal, S. (2010) 'India is No. 2 in Mobile Net Use', DNAIndia.com, [online], 31 March. Accessible at http://www.dnaindia.com/money/report india-is-no-2-in-mobile-netuse 1365476. Accessed 28 March 2011

Facebook (2013) Key Facts, [online]. Accessible at http://newsroom.fb.com/Key-Facts. Accessed 19 April 2013

Gauntlett, D. and Horsley, R. (2000) Web.Studies, $2^{\text {nd }}$ Ed., London: Oxford University Press

Granovetter, M. (1973) 'The Strength of Weak Ties', American Journal of Sociology, 78(6), $1360-80$

Haraway, D. (1991) Simians, Cyborgs, and Women: The Reinvention of Nature, New York: Routledge

Hariche, A. C., Loiseau, E. and MacErlaine, R. (2011) 'Web-Enabled Social Cohesion: Harnessing Participation', International Conference on Social Cohesion and Development., OECD Development Centre, Paris, France, 20-21 January.

Hanisch, C. (2006) 'The Personal is Political', [online]. Accessible at http://www.carolhanisch.org/CHwritings/PIP.html. Accessed 14 June 2011

Hinyard, L. J. and Kreuter, M. W. (2006) 'Using Narrative Communication as a Tool for Health Behaviour Change: A Conceptual, Theoretical and Empirical Overview', Health Education and Behaviour, 34(5), 777-92 
Holland, M. G. (1996) 'What's Wrong with Telling the Truth? An Analysis of Gossip', American Philosophical Quarterly, 33(2), 197-209

Huhtamo, E. (1995) 'Seeking Deeper Contact: Interactive Art as Metacommentary', Convergence: The International Journal of Research into New Media Technologies, 1(2), 81104

IBNLive (2013) 'Delhi gangrape: Timeline from December 16 to March 11', [online], n.d.. Accessible at http://ibnlive.in.com/news/delhi-gangrape-timeline-from-december-16-tomarch-11/377932-3-244.html. Accessed 25 September 2013

Kendon, A., Harris, R. M. and Key, M. R. (1975) Organization of Behavior in Face-to-face Interaction, The Hague: De Greuter

Knights, M. (2007) 'Web 2.0 [Web Technologies]', Communications Engineer, 5(1), 30-35

Laver, J. (1975) 'Communicative Functions of Phatic Communion', in A. Kendal, R. M. Harris and M. R. Key (eds), Organisation of Behaviour in Face-to-Face Interaction. The Hague: De Greuter, pp. 215-38

Ledbetter, A. M., Mazer J. P., DeGroot, J. M., Meyer, K. R., Mao, Y. and Swafford, B. (2011) 'Attitudes Toward Online Social Connection and Self-disclosure as Predictors of Facebook Communication and Relational Closeness', Communication Research, 38(1), 2753

Lehr, W. and McKnight, L. W. (2003) 'Wireless Internet Access: 3G vs Wifi', Telecommunications Policy 27(6), 351-70

Licoppe, C. and Smoreda, Z. (2005) 'Are Social Networks Technologically Embedded? How Networks are Changing Today with Changes in Communication Technology', Social Networks, 27, 317-35

Miller, V. (2008) 'New Media, Networking and Phatic Culture', Convergence: The International Journal of Research into New Media Technologies, 14(4), 387-400

Mohanty, C. T. (2003) Feminism Without Borders: Decolonizing Theory, Practicing Solidarity, London: Duke University Press

Mishra, G. (2009) 'Three Lessons Activists and Marketers Can Learn From India's Valentine's Day Pink Panty Campaign', Gauravonomics.com, [online], 25 February. 
Accessible at http://www.gauravonomics.com/blog/three-lessons-activists-and-marketerscan-learn-from-indias-valentines-day-pink-panty-campaign/. Accessed 26 September 2011

Naughton, J. (2006) 'Net Benefit: How the Internet is Transforming our World',Annual Lecture of the UK Marketing Society, delivered 28 February, Science Museum, London

Paine, R. (1967) 'What is Gossip About? An Alternate Hypothesis', Man, 2(2), 278-85

Parashar, S. (2013) 'The Delhi Rape Case: Rethinking Feminism and Violence Against Women', e-International Relations, [online], 11 February. Accessible at http://www.eir.info/2013/02/11/the-delhi-rape-case-rethinking-feminism-and-violence-against-women/. Accessed 12 November 2013

Parr, B. (2010) 'The First Thing Young Women Do in the Morning: Check Facebook', Mashable.com, [online], 7 July. Accessible at http://mashable.com/2010/07/07/oxygenfacebook-study. Accessed 26 September 2011

Pempek, T. A., Yermolayeva, Y. A. and Calvert, S. L. (2009) 'College Students' Social Networking Experiences on Facebook', Journal of Applied Developmental Psychology, 30(3), 227-38

Peters, J. D. (1993) 'Distrust of Representation: Habermas on the Public Sphere', Media, Culture \& Society, 15: 541-71

Petrecca, L. (2008) 'Offended Moms Get Tweet Revenge Over Motrin Ads', USAToday.com, [online], 19 November. Accessible at http://usatoday30.usatoday.com/tech/products/2008-1118-motrin-ads-twitter_N.htm. Accessed 4 October 2013

Plant, S. (1998) Zeros and Ones: Digital Women and the New Technoculture, London: Fourth Estate

Putnam, R. D. (2000) Bowling Alone: The Collapse and Revival of American Community, New York: Simon \& Schuster

Rapleaf (2008) 'Rapleaf Study on Social Network Users vs. Age', Rapleaf.com, [online], n.d. Accessible at https://www.rapleaf.com/press/age. Accessed 26 September 2011

Reinharz, S. (1983) 'Women as Competent Community Builders the Other Side of the Coin', Informa Healthcare, 5(1-4), 19-43 
Ross, C., Orr E. S., Sisic, M., Arseneault, J. M., Simmering, M. G. and Orr, R. R. (2009) 'Personality and Motivations Associated with Facebook Use', Computers in Human Behavior, 25(2), 578-86

Rysman, A. (1977) 'How the “Gossip” Became a Woman', Journal of Communication, 27(1), $176-80$

Sassen, S. (2002) 'Mediating Practices: Women With/In Cyberspace', in J. Armitage and J. Roberts (eds) Living with Cyberspace: Technology and Society in the $21^{\text {st }}$ Century, New York: Continuum, pp. 109-19

Shapiro, C. and Varian H. R. (1999) Information Rules: A Strategic Guide to the Network Economy, Boston, MA: Harvard Business School Press

Singh, S. (2010) 'Digital Divide in India: Measurement, Determinants and Policy for Addressing the Challenges in Bridging the Digital Divide', International Journal of Innovation in the Digital Economy, 1(2), 1-24

Smith J. (2009) 'Fastest Growing Demographic on Facebook: Women Over 55', InsideFacebook.com, [online], 2 February. Accessible at http://www.insidefacebook.com/2009/02/02/fastest-growing-demographic-on-facebookwomen-over-55/. Accessed 23 September 2013

Spacks, P. M. (1982) 'In Praise of Gossip', The Hudson Review, 35(1), 19-38

Spender, D. (1995) Nattering on the Net. Melbourne: Spinifex

Tachhi, J. (2010) 'Technologies of Sound and Affect in Domestic Space', Emotional Geographies Conference, University of South Australia, Adelaide, 6-8 April.

Turkle, S. (1984) The Second Self: Computers and the Human Spirit, Cambridge, MA: MIT Press

Turkle, S. (2011) Alone Together: Why We Expect More from Technology and Less from Each Other, New York: Basic Books

van Dijk, J. (2000) 'Models of Democracy and Concepts of Communication', in K. Hacker and J. van Dijk (eds), Digital Democracy: Issues of Theory and Practice, [eBook], Sage Publications, pp. 30-53 
van Zoonen, L. (2001) 'Feminist Internet Studies', Feminist Media Studies, 1(1), 67-72

Wajcman, J. (2004) Techno Feminism, Cambridge: Polity Press

Wood, J. (2008) Gendered Lives, 7th Belmont, CA: Wadsworth/Thomson Learning

World Bank (n.d.) India: Reducing Poverty, Maximising Growth, [online]. Accessible at http://siteresources.worldbank.org/IDA/Resources/73153-

1285271432420/IDA_AT_WORK_India.pdf. Accessed 12 November 2013 